Corrigendum

\title{
Corrigendum to "Detarium microcarpum, Guiera senegalensis, and Cassia siamea Induce Apoptosis and Cell Cycle Arrest and Inhibit Metastasis on MCF7 Breast Cancer Cells"
}

\author{
Ismail Abiola Adebayo, ${ }^{1}$ Haladu Ali Gagman,, ${ }^{2,3}$ Wasiu Gbolahan Balogun, \\ Mowaffaq Adam Ahmed Adam, ${ }^{4}$ Rafedah Abas, ${ }^{5}$ Khalid Rehman \\ Hakeem, ${ }^{6}$ Nik Ahmad Irwan Izzauddin Bin Nik Him, ${ }^{2}$ \\ Muhammad Razip Bin Samian, ${ }^{2}$ and Hasni Arsad (iD) \\ ${ }^{1}$ Integrative Medicine Cluster, Advanced Medical and Dental Institute, Universiti Sains Malaysia, Bertam, \\ 13200 Kepala Batas, Pulau Pinang, Malaysia \\ ${ }^{2}$ School of Biological Sciences, Universiti Sains Malaysia, George Town, 11800 Penang, Malaysia \\ ${ }^{3}$ Department of Biological Sciences, Faculty of Sciences, Bauchi State University Gadau, 751 Itas Gadau, Nigeria \\ ${ }^{4}$ Infectomics Cluster, Advanced Medical and Dental Institute, Universiti Sains Malaysia, George Town, Penang, Malaysia \\ ${ }^{5}$ Centralized Research Labs (CRL), Advanced Medical and Dental Institute USM, Bertam, 13200 Kepala Batas, Penang, Malaysia \\ ${ }^{6}$ Department of Biological Science, Faculty of Science, King Abdulaziz University, P.O. Box 80203, Jeddah, Saudi Arabia
}

Correspondence should be addressed to Hasni Arsad; hasniarsad@usm.my

Received 6 August 2019; Accepted 8 August 2019; Published 8 September 2019

Copyright ( 2019 Ismail Abiola Adebayo et al. This is an open access article distributed under the Creative Commons Attribution License, which permits unrestricted use, distribution, and reproduction in any medium, provided the original work is properly cited.

In the article titled "Detarium microcarpum, Guiera senegalensis, and Cassia siamea Induce Apoptosis and Cell Cycle Arrest and Inhibit Metastasis on MCF7 Breast Cancer Cells" [1], an acknowledgment should be added as follows:

The article is partially funded by USM-Bridging Grant: (304.CIPPT.6316239).

\section{References}

[1] I. A. Adebayo, H. A. Gagman, W. G. Balogun et al., "Detarium microcarpum, Guiera senegalensis, and Cassia siamea induce apoptosis and cell cycle arrest and inhibit metastasis on MCF7 breast cancer Cells," Evidence-Based Complementary and Alternative Medicine, vol. 2019, Article ID 6104574, 12 pages, 2019. 


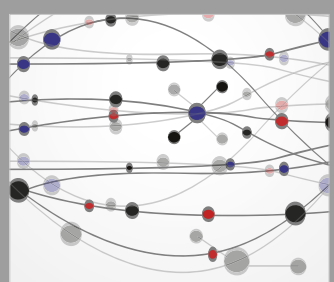

The Scientific World Journal
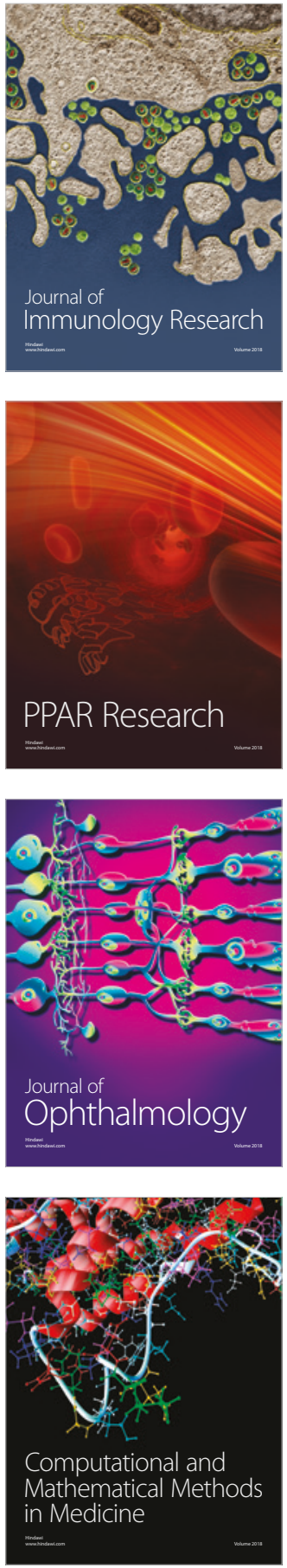

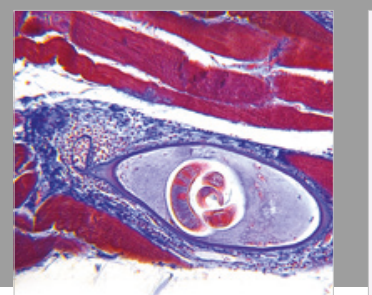

Gastroenterology Research and Practice

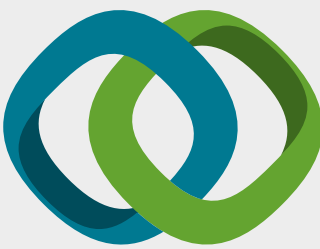

\section{Hindawi}

Submit your manuscripts at

www.hindawi.com
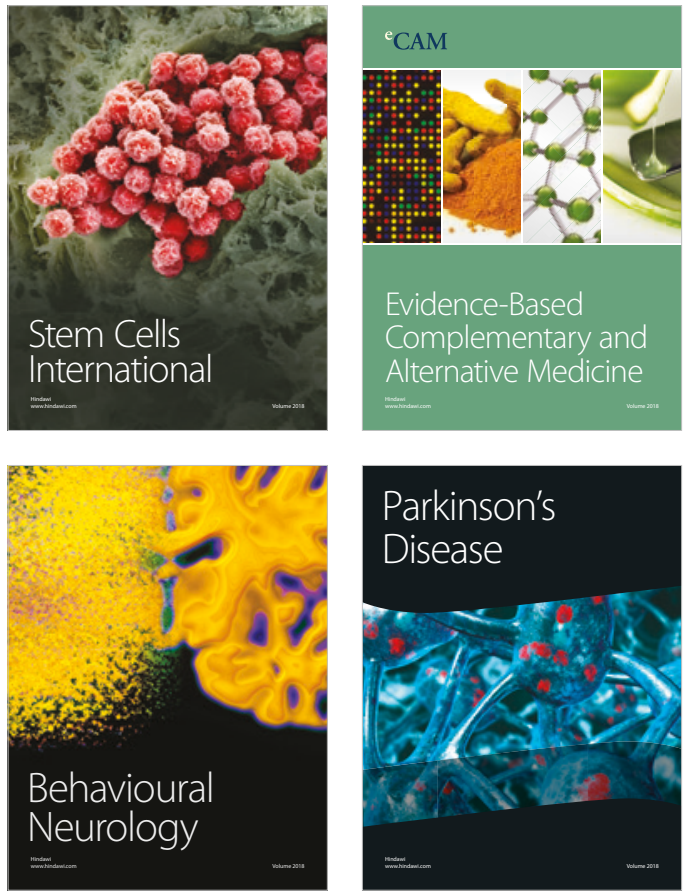

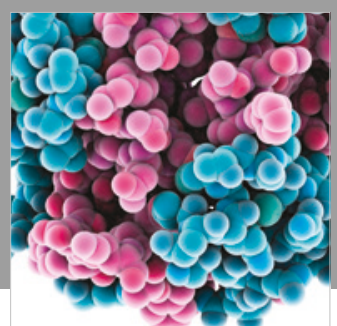

ournal of

Diabetes Research

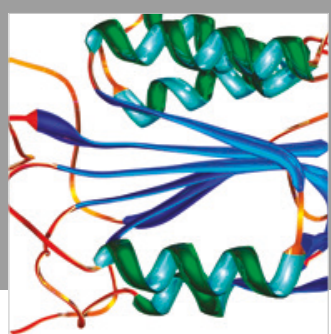

Disease Markers
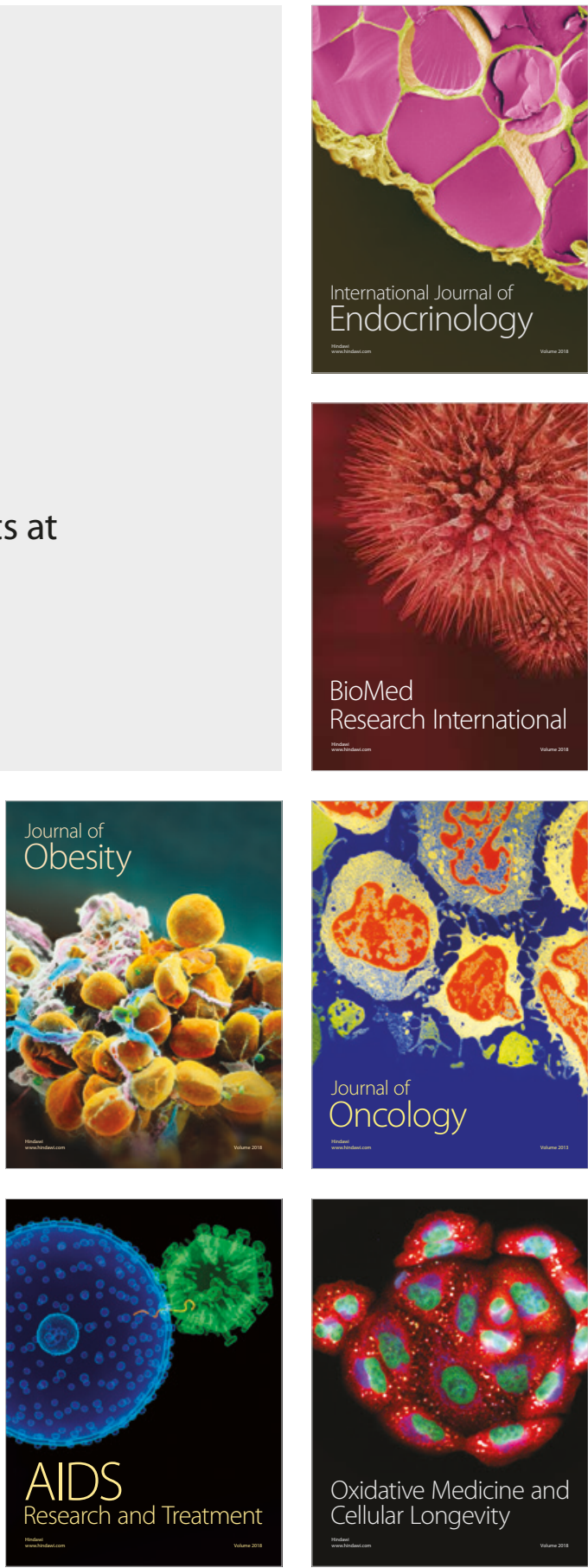